\section{Cacao families and parents selected as resistant to natural infection of Moniliophthora perniciosa}

\author{
Carolina S. Benjamin ${ }^{1 *}$, Edna Dora M. N. Luz², Wedisson O. San- \\ tos $^{1}$ and José L. Pires ${ }^{3}$
}

\begin{abstract}
The known sources of resistance to witches' broom (WB), a severe disease of cacao, are limited. Aiming to identify families and parents resistant to Moniliophthora perniciosa, a population of 22 families was evaluated by assessing the number of brooms formed per tree during 10 years under field conditions. The population was established in randomized blocks with three replications of 12 plants each. Significant differences were observed among families. The most outstanding families were NA33 $\times$ RB39 and RB39 $\times$ P4B, which presented the lowest WB incidence during 10 years. The increase in natural field infection of Scavina clones families and their descendants were clearly demonstrated after 2006. The existence of additive effects for resistance appears clearly for families, which had other source of resistance associated with Scavina. Clones RB39, RB36, P4B, NA33 and CSUL3 are promising parents for pyramiding resistance genes and increasing the stability and durability of resistance to $W B$.
\end{abstract}

Key words: Theobroma cacao, resistance, genetic breeding.

\section{INTRODUCTION}

Cacao culture (Theobroma cacao L.) involves approximately two million producers in more than 50 countries (Knight 2000). In 2013, the world production of cacao was estimated at about 4 million tons: Africa produced 2.823 million tons, the Americas produced 622,000 tons, and Asia and Oceania produced 483,000 tons (ICCO 2014).

Brazil is the second largest cacao exporter, and the state of Bahia led the national production between the years of 1976 and 1987. Nowadays, it continues to be the largest producing state; however, its participation dropped significantly in the national production. Cacao agribusiness made such progress, which culminated in the consolidation of an export agro industrial complex, recognized as the most modern in the world. In this phase, the largest cacao beans processor was implanted in southern Bahia, surpassing the milling capacity of the US, the Netherlands, Germany and Russia. Currently, Brazil has the sixth miller park in the world, which accounts for $6 \%$ of cacao processing, with capacity of about 202,000 tons (Midlej and Santos 2012). However, in 1989, witch's broom disease (WB) was found in the cacao region of southern Bahia. Due to favorable environmental conditions, the disease spread rapidly, reaching epidemic proportions and causing, in short time, serious social and economic problems in the region (Oliveira and Luz 2005).
Crop Breeding and Applied Biotechnology 16: 141-146, 2016 Brazilian Society of Plant Breeding. Printed in Brazil http://dx.doi.org/10.1590/1984$70332016 v 16 n 2 a 21$

\footnotetext{
*Corresponding author: E-mail:carolinabenjamin_1@hotmail.com

Received: 20 March 2015 Accepted: 11 December 2015

${ }^{1} 1$ Universidade Federal de Viçosa (UFV), Departamento de Solos, Laboratório de Fertilizantes, Avenida P.H. Rolfs, 36.570-900, Viçosa, MG, Brazil

${ }^{2}$ Centro de Pesquisas do Cacau (CEPEC), Seção de Fitopatologia, 45.600-000, Itabuna, BA, Brazil

${ }^{3}$ CEPEC, Seção de Genética
} 


\section{CS Benjamin et al.}

WB, along with structural factors, such as plants aging, since there is no plantations renewal (Santos Filho et al. 2008), and with circumstantial factors, such as low price in the domestic market, high production cost, exchange rate losses and lack of financing, reduced the participation of cacao Brazilian production on the world market from 15 to 4.3\% between the years of 1989 and 1998 (Peres Filho 1998), transforming Brazil from typically exporter to a cacao importer. Currently, Brazil is the sixth main world producer, accounting for $4.4 \%$ of cacao world production (ICCO 2014).

After the introduction of WB in Bahia, the Cacao Research Center of the Executive Commission of the Cacao Farming Plan (Ceplac/Cepec) has sought to offer to producer's cacao varieties resistant to this disease, and which are agriculturally more competitive and superior to those cultivated in the region. Thus, it was used the reserves of germplasm banks of Bahia, containing clones introduced from other countries, mainly from Trinidad, Costa Rica, as well as those from the Brazilian Amazon (SUEPA/Ceplac). Only in the Amazon region, it was obtained materials from more than 30 river basins of the northern Amazon region, from wild and domesticated cacao (Monteiro and Ahnert 2012).

At first, the only available source of resistance was Scavina clones (SCA) and their descendants, which were used by the Cacao Breeding Program (PMGC), although it was known that the behavior of these clones varied in other regions. In the early twenty-first century, it was detected pathogen variations in cacao populations of Bahia, evidencing the need to expand the resistance sources within the PMGC (Paim et al. 2006).

Thus, the use of genotypes which comprise a larger number of different genes linked to resistance became the strategy for obtaining more durable resistance (Monteiro and Ahnert 2012). Furthermore, it was necessary constant characterization of selected materials in the cacao region of Bahia, in order to identify genotypes with genes linked to resistance, with the aim of obtaining varieties with more durable resistance (Faleiro et al. 2004).

Structured-type population-base was generated in CEPEC from 1997, in combinations which produced the series of individuals which were tested by screening for WB resistance, by artificially inoculating them with $10^{4}$ basidiospores $\mathrm{mL}^{-1}$. Seedlings, which presented no symptoms, were transferred to the experimental fields and were evaluated in the field in relation to natural infection by M. perniciosa (Silva et al. 2010).

Thus, the aim of this study was to select progenies and parents resistant to WB, based on a population composed of 22 progenies evaluated for ten years under conditions of natural infection.

\section{MATERIAL AND METHODS}

The cacao population used in this study consisted of 22 progenies using seminal seedlings, in May 1999, at the Experimental Station Arnaldo Medeiros (ESARM) of the Cacao Research Center Ceplac (lat 14 45' 15" S, long 39 13' $59^{\prime \prime} \mathrm{W}$, and alt $50 \mathrm{~m}$ asl), in the municipality of Ilhéus, Bahia. Among these progenies, Scavina 6 (SCA6), Scavina 12 (SCA12), and Theobahia were used as intermediate resistance pattern, and Catongo was used as susceptible pattern. The pattern progenies originated from open-pollination, while the remaining 19 progenies originated from the crosses: CEPEC86 x CEPEC89, CEPEC86 x SCA6, CSUL3 x CA5, CSUL3 x M0Q216, SCA6 x SIC813, RB36 x ICS1, RB36 x SCA6, RB3 $x$ CHUAO120, NA33 x RB39, SIAL70 x CHUA0120, RB36 x CA5, RB36 x SCA12, CEPEC86 x CSUL7, ICS9 x OC67, CSUL3 $x$ ICS1, P4B x EEG29, CSUL3 x SCA6, P4B x RB39, SGU26 x SCA6. These codes mean: CEPEC- Cacao Research Center; SCAScavina; - CSUL- Cruzeiro do Sul; CA- Careiro; MOQ-Mocorongo; SIC- Seleção do Instituto de Cacau; RB- Rio Branco; CHUAO- Valle do Chuao; NA- Nanay; SIAL- Seleção Instituto Agronômico do Leste; ICS- Imperial College Selection; OCOcumare; P4B- Pound; EEG- Estação Experimental Goytacazes; SGU- Seleção Guatemala.

Crosses were designed aiming at combining resistance sources to WB and other desirable agronomic traits. In the field, these progenies were planted at $3.0 \times 3.0 \mathrm{~m}$ spacing, in an established cacao crop, which had already been established in the same spacing and were highly infected with WB, in order to create high pressure of $M$. perniciosa inoculum in the area, aiming at exposing the genetic material to natural infection.

Each treatment consisted of one progeny, arranged in the field in a randomized block design with three replications with 12 plants each, totaling 36 plants per treatment or progeny. The experiment was installed in 1999 with plants, which had been artificially inoculated in greenhouse and had not presented disease symptoms. The counting of the number of brooms began in 2000, a year after the establishment of plants in the field, because until that time, canopy had not been formed. Quantification of the number of brooms formed in each plant of the progeny was carried out when they 
were removed. Initially, counting was carried out monthly, and it did not consider the type of broom, and after that, it was carried out only during the removal periods, four times a year. This work continued until the year of 2011, with the exception of 2010, when there was no evaluation, completing 10 years of data.

The experiment includes crosses between parents, clones considered as resistance sources, such as NA33, P4B, RB36 and RB39, CEPEC89, CHUAO120, CSUL7 and CSUL3, with different geographical origins and which were genetically distant (Marita et al. 2001). Other materials were selected for their good production characteristics, such as: ICS 1 and ICS 9, SGU26, SIAL70, SIC813, EEG29, OC67 and CA5.

The variable considered for analysis was the mean number of brooms per plant year ${ }^{-1}$, and each evaluation year was also considered as a variable, using the multivariate analysis of variance for unbalanced data (GLM- Manova) for the study of progeny effects and replication within progenies. For the interpretation of the effects progenies $\mathrm{x}$ year interactions, it was used the analysis of repeated measures (GLM- Repetead). All the studied progenies were compared by contrasts with the SCA6, which was used as resistance pattern, and at the same time, as differentiator of resistance genes. For comparisons of means unbalanced data, it was used the LSMEANS Tukey-Kramer test. All statistical procedures were carried out with the SAS (1988) software.

\section{RESULTS AND DISCUSSION}

Since only three plants survived within the Catongo progeny, this progeny was not considered in the analysis of the experiment. Death of the plants of Catongo progeny was a consequence of infection by M. perniciosa in the experimental field, evidencing that the inoculum pressure in the area was suitable for selection of resistance to the pathogen.

Multivariate analysis detected highly significant differences for progenies and replication within progenies (F probability for the Wilks test $=0.0001$ ), demonstrating differences in reaction to the disease among the studied progenies.

In the analysis of repeated measures, year $\mathrm{x}$ progeny interactions were significant ( $\mathrm{F}$ probability for the Willk test = 0.0001). It was identified the occurrence of variation in the resistance behavior throughout the years among progenies. The development of base-population in Cepec aimed to support the clonal selection program, by combining these populations, which are different resistance sources to WB, and thus promoting the accumulation of resistance genes, as well as the association of desirable agronomic traits, especially for production (Monteiro and Ahnert 2012).

The significant effect of progenies indicates diversity in behavior regarding the reaction to the pathogen and possible interaction between genes of the different resistance sources, as evidenced by the evolution of the mean number of brooms per plant for the ten years of evaluation (Table 1 and Figure 1). In the first five years of evaluation, progenies showed reduced mean number of vegetative brooms, with sharp increase from the year of 2006 (Figure 1 and Table 1). Progenies of Theobahia, Scavina 6 (SCA6), Scavina 12 (SCA12), and those originated from crosses in which one of these clones was used as parent (SGU26 x SCA6, SCA6 $x$ SIC813) showed sharp increase in the number of brooms from 2007 to 2011. However, other three progenies (RB36 x SCA6, RB36 x SCA12 and CSUL3 x SCA6), which also had the clones SCA6 and SCA12 as ascendant or parents, did not present this increase over the years, indicating additive effect of resistance genes from another ascendant clone.

The sharp increase in the incidence of WB from 2006 may be associated with climatic factors, and/or break of the resistance by the pathogen. In Bahia, the favorable conditions for disease are found almost throughout the year, except when rainfall is less than $100 \mathrm{~mm}$ monthly, or when there is an increase in temperature with decrease

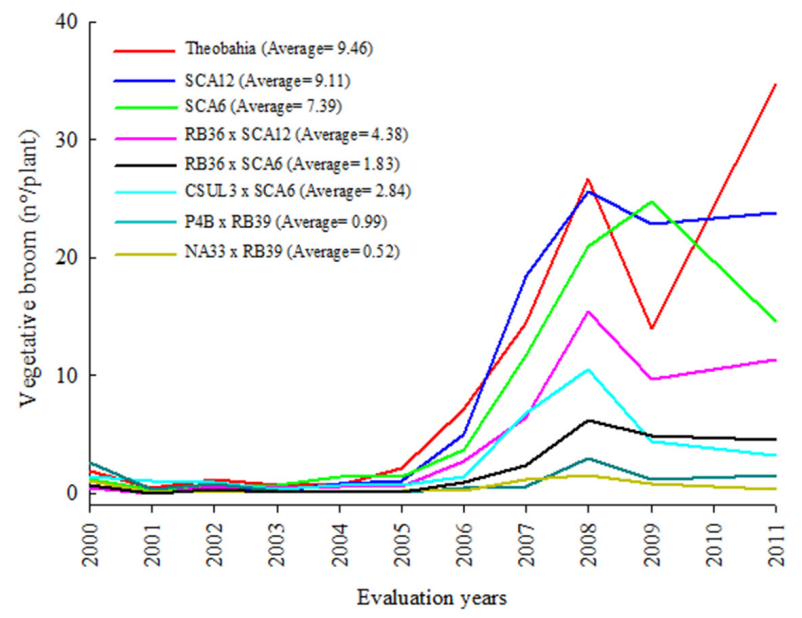

Figure 1. Mean number of vegetative brooms per plant in cacao progenies evaluated in the field for ten years. 
Table 1. Mean number of vegetative brooms per plant in 22 cacao progenies evaluated in the field from 2000 to 2011

\begin{tabular}{|c|c|c|c|c|c|c|c|c|c|c|c|c|}
\hline \multirow{2}{*}{ Progenies } & \multicolumn{11}{|c|}{ Years } & \multirow{2}{*}{ Overall mean } \\
\hline & 2000 & 2001 & 2002 & 2003 & 2004 & 2005 & 2006 & 2007 & 2008 & 2009 & 2011 & \\
\hline Theobahia & 1.9 & 0.5 & 1.2 & 0.7 & 0.6 & 2.1 & 7.2 & 14.4 & 26.7 & 14.0 & 34.7 & 9.46 \\
\hline SGU26xSCA6 & 0.1 & 0.0 & 0.1 & 0.1 & 1.5 & 1.2 & 7.2 & 20.2 & 29.0 & 28.0 & 13.3 & 9.16 \\
\hline SCA12 & 1.1 & 0.1 & 0.3 & 0.2 & 0.8 & 1.0 & 5.0 & 18.4 & 26.6 & 22.9 & 23.9 & 9.11 \\
\hline SCA6xSIC813 & 0.9 & 0.8 & 1.3 & 0.6 & 1.0 & 3.0 & 7.1 & 13.6 & 22.5 & 18.1 & 16.8 & 7.8 \\
\hline ICS9xOC67 & 6.0 & 3.7 & 3.5 & 1.9 & 2.4 & 2.1 & 3.0 & 21.0 & 18.8 & 9.9 & 13.3 & 7.78 \\
\hline CEPEC86xCSUL7 & 2.5 & 2.7 & 5.1 & 2.2 & 1.4 & 4.0 & 7.2 & 17.8 & 11.9 & 10.9 & 6.8 & 6.58 \\
\hline CSUL3xCA5 & 4.7 & 1.2 & 3.2 & 1.5 & 1.3 & 2.3 & 4.6 & 13.7 & 11.0 & 10.9 & 7.7 & 5.65 \\
\hline RB36xCA5 & 3.4 & 1.3 & 4.2 & 1.8 & 2.0 & 2.5 & 4.5 & 7.1 & 9.7 & 10.6 & 13.6 & 5.53 \\
\hline CSUL3xICS1 & 6.9 & 4.4 & 3.0 & 2.0 & 1.7 & 2.5 & 2.8 & 10.2 & 11.4 & 7.1 & 4.8 & 5.16 \\
\hline SIAL70xCHUAO120 & 4.9 & 3.6 & 2.7 & 0.9 & 1.9 & 2.5 & 5.5 & 6.8 & 13.3 & 9.9 & 4.2 & 5.1 \\
\hline CSUL3xMOQ216 & 3.9 & 2.5 & 4.5 & 2.1 & 2.4 & 1.9 & 5.6 & 4.8 & 9.0 & 5.6 & 4.2 & 4.22 \\
\hline RB36xCHUAO120 & 1.6 & 1.4 & 1.0 & 0.3 & 0.7 & 1.4 & 2.4 & 6.2 & 8.6 & 6.1 & 7.9 & 3.4 \\
\hline CSUL3xSCA6 & 1.4 & 1.1 & 0.9 & 0.3 & 0.6 & 0.6 & 1.4 & 6.8 & 10.5 & 4.5 & 3.2 & 2.84 \\
\hline RB36xSCA6 & 0.7 & 0.0 & 0.3 & 0.1 & 0.1 & 0.1 & 0.9 & 2.4 & 6.2 & 4.9 & 4.5 & 1.83 \\
\hline CEPEC $86 \times$ CEPEC 89 & 0.1 & 0.0 & 1.1 & 0.6 & 0.1 & 0.3 & 0.9 & 4.1 & 3.8 & 2.7 & 4.3 & 1.63 \\
\hline P4BxRB39 & 2.6 & 0.3 & 0.8 & 0.2 & 0.1 & 0.1 & 0.4 & 0.6 & 3.0 & 1.2 & 1.6 & 0.99 \\
\hline NA33xRB39 & 1.0 & 0.1 & 0.2 & 0.1 & 0.1 & 0.2 & 0.2 & 1.1 & 1.6 & 0.8 & 0.3 & 0.52 \\
\hline
\end{tabular}

in relative humidity. According to Luz et al. (2006), the rainfall periods and the air humidity above $90 \%$, associated with average temperatures below $24^{\circ} \mathrm{C}$, potentiate sporophore production, and consequently the development of the disease. In addition to climatic factors, changes in the pathogen population may have evolved to resistance break. Due to the large increase in the incidence of WB for open-pollinated progenies of SCA6 and SCA12 and their descendants, especially Theobahia (Figure 2), it is suggested that there was genetic resistance break to WB.

Theobahia (Alto Amazonas river x Trinitário), since it has been released as seminal variety, has distinguished itself due to its high yield, about $2,250 \mathrm{~kg} \mathrm{ha}^{-1}$ year ${ }^{-1}$. However, it is no longer recommended for planting due to its susceptibility to Ceratocystis wilt, caused by the fungus Ceratocystis cacaofunesta (Bezerra 1997, Bezerra et al. 1998).

The behavior of the progenies SCA6 and SCA12 were similar (Table 1 and Figure 1). However, for their descendants, there was a variation in the resistance expression. The increase in the mean number of brooms for the progenies SGU26 x SCA6, SCA6 x SIC813, SCA6 and SCA12 shows resistance break due to the pathogen evolution. In contrast, the progenies RB36 $\times$ SCA6, RB36 $\times$ SCA12, CSUL3 $\times$ SCA6 and CEPEC86 $\times$ SCA6demonstrated lower incidence of WB over the years, when compared with the progenies mentioned above, possibly due to the contribution of the other parent, whose resistance genes hindered the infection by the pathogen. Paim et al. (2006) found behavioral changes for the progenies SCA6 and SCA12 in relation to the increase in the incidence of WB in Cepec areas, from 2004, which was also observed in other areas of Cepec. This fact evidenced the evolutionary process of the pathogen with the increase in the pathogen population of types, which were more aggressive to SCA clones. Similar results were obtained by Albuquerque et al. (2010).

Pires et al. (1999), in a study of association between resistance sources to WB for the increment of the level and of the durability of the trait, noted that SCA, when crossed with other resistant parents, maintained low level of infection in areas where the pathogen evolution was present, while progenies which had only SCA as resistant parent presented high level of infection, proving the increased resistance durability due to the combination of different genes.

When SCA6 progeny was contrasted with other progenies (Table 2), it was observed that 12 of the 21 progenies were 
distinct from SCA6, presenting better performance when compared with this progeny isolated. This shows, again, the influence of other sources to ensure resistance against the development of the pathogen. Thus, descendants clones of SCA in the first, second or third generation may still be recommended to replace susceptible plants to WB, as highlighted by Pires et al. (1999). For that, it is necessary, for the cross of all generations, the presence of other clones, which are resistance sources, aiming to amplify the resistance base and durability.

Among the progenies CEPEC86 x CEPEC89, CEPEC86 $x$ CSUL7 and CEPEC86 $\times$ SCA6, the first cross stood out in relation to the smaller number of brooms. The genotypes of the Cepec series are descendants of the traditional varieties of Bahia. CEPEC86, selected in the Jequitinhonha River Valley by Basil Bartley, showed low level of infection to $W B$, justifying the best performance of the progeny CEPEC86 x CEPEC89 in this work.

Progenies CSUL3 $\times$ CA5, CSUL3 $\times$ ICS1 and CSUL3 $x$ MOQ216, which had CSUL3 as parent, also showed resistance variation over the years. However, all the crosses involving the clone CSUL3, including that with SCA6 as the other parent, presented reduction in the mean number of WB in the last two years of evaluation (Table 1). This behavior for the materials of Cruzeiro do Sul (CSUL) corroborate the results obtained by Marita et al. (2001), who classified the materials as resistant in southern Bahia.
Table 2. Values of probability error for rejection of the null hypothesis of the contrasts between the means of the studied progenies and of the progeny Scavina 6

\begin{tabular}{lc} 
& Contrast - Scavina6 \\
\cline { 2 - 2 } Progênies & Pr $\mathbf{F}$ \\
CEPEC86xCSUL7 & $<0.0001^{*}$ \\
CSUL3xCA5 & $<0.0001^{*}$ \\
CSUL3xICS1 & $<0.0001^{*}$ \\
CSUL3xMOQ216 & $<0.0001^{*}$ \\
ICS9xOC67 & $<0.0001^{*}$ \\
P4BxRB39 & $<0.0001^{*}$ \\
RB36xCA5 & $<0.0001^{*}$ \\
RB36xICS1 & $<0.0001^{*}$ \\
Theobahia & $<0.0001^{*}$ \\
NA33xRB39 & $0.0010^{*}$ \\
P4BxEEG29 & $0.0026^{*}$ \\
SIAL70xCHUAO120 & $0.0062^{*}$ \\
RB36xSCA6 & $0.0139^{*}$ \\
CSUL3xSCA6 & $0.0293^{*}$ \\
RB36xCHUAO120 & 0.0197 \\
SCA6xSIC813 & 0.0591 \\
SCA12 & 0.2056 \\
RB36xSCA12 & 0.2254 \\
SGU26xSCA6 & 0.7134 \\
CEPEC86xSCA6 & 0.7687 \\
CEPEC86xCEPEC89 & 0.9356 \\
\hline DesCrivtie & \\
\hline
\end{tabular}

* Descriptive level for $\mathrm{F}$, considering the Wilk's Lambda test significant at $5 \%$.

The behavior presented by the progenies NA33 $\times$ RB39 and P4B $\times$ RB39 during the 10 years of evaluation in relation to resistance shows that these materials were superior, indicating that the clone RB39 is a highly promising resistance source, since it promoted resistance durability when combined with other sources. Furthermore, progenies descendant of CSUL also presented good performance in terms of resistance. However, they did not stand out as the RB39 material (Table 1), although both originate from the same place, the state of Acre, but from different basins.

Clones of CSUL and RB, from Acre, through the screening project and in other experiments carried out in the state of Bahia, were evaluated as distinct resistance sources of Scavina clones (Luz et al. 1997, Silva and Matsuoka 1999). Fonseca and Albuquerque (2000) evaluated resistance levels of 521 clonal accessions in the Alto, Médio and Baixo Amazonas river, in high-pressure inoculum condition for four years. These authors classified 180 of these clones as promising, most belonging to $C A B, R B$ and $B E$. Almeida et al. (2009), found similar results, highlighting the CAB series as well.

This research presents a classic example of pyramiding of genes, i.e., resistance sources of different materials were clustered in the same genotype. Thus, results obtained in this study confirmed those obtained by Silva et al. (2010) and others authors, in which RB39, NA33, P4B, RB36 and CSUL3 are highly recommended for PMGC as parents for new crosses, aiming at the association of genes for resistance to $W B$, at the expanding genetic diversity, and at greater resistance durability.

\section{ACKNOWLEDGEMENTS}

The authors thank Ceplac/Cepec for the infrastructure and support; the World Cacao Foundation (WCF) for the support in the establishment of the experiments and in the evaluations; and CAPES and CNPq, for the scholarships granted to the $1^{\text {st }}$ and $2^{\text {nd }}$ authors, respectively. 


\section{REFERENCES}

Albuquerque PSB, Silva SDVM, Luz EDMN, Pires JL, Vieira AM, Demetrio CGB, Pascholatti SF and Figueira A (2010) Novel sources of witches broom resistance (causal agent Moniliophthora perniciosa) from natural populations of Theobroma cacao from the Brazilian Amazon. Euphytica 172: 125-138.

Almeida CMVC, Dias LAS and Silva AP (2009) Agronomical characterization of cacao accessions. Pesquisa Agropecuária Brasileira 44: 368-373.

Bezerra JL (1997) Ceratocystis fimbriata causing death of budded cacao seedlings in Bahia, Brazil. Incoped Newsletter 1:6.

Bezerra JL, Almeida OC, Luz EDMN and Silva SDV (1998) Ocorrência de Ceratocystis fimbriata em clones de cacau no estado da Bahia. Fitopatologia Brasileira 23: 228.

Faleiro ASG, Faleiro FG, Lopes UV, Melo GRP, Monteiro WR, Yamada M M, Bahia RCS and Corrêa RX (2004) Variability in cacao selected by producers for resistance to witches' broom based on microsatellite markers. Crop Breeding and Applied Biotechnology 4: 290-297

Fonseca SEA and Albuquerque PSB (2000) Avaliação de clones de cacau na Amazônia Brasileira em relação a incidência de vassoura-de-bruxa. In Informe de Pesquisa 1997-2003. CEPLAC, Superintendência do Estado do Pará, Belém, p. 64-78.

ICCO - International Cacao Organization (2014) The cacao market situation. Available at <http://www.icco.org/about-us/internationalcacao-agreements/>. Acessed in November, 2015

Knight C (2000) Cacao review: supply and demand trends. American Cacao Research Institute. Available at: <http://www.acricacao.org/ acri/index>. Acessed in June, 2012.

Luz EDMN, Bezerra JL, Resende MLV and Oliveira ML (1997) Cacau (Theobroma cacao L.) Controle de doenças. In Ribeiro do Vale FX and Zambolim L (eds) Controle de doenças de plantas-grandes culturas. Editora UFV, Viçosa, p. 617-622.

Luz EDMN, Souza JT, Oliveira ML, Bezerra JL and Albuquerque PSB (2006) Vassoura-de-bruxa do cacaueiro: novos enfoques sobre uma velha doença. Revisão Anual de Patologia de Plantas 14: 59-111.
Marita JM, Nienhuis J, Pires JL and Aitken WM (2001) Analysis of genetic diversity in Theobroma cacao with emphasis on witches ' broom disease resistance. Crop Science 41: 1305-1316.

Midlej RR and Santos AM (2012) Economia do cacau. In Valle RR (ed) Ciência, tecnologia e manejo do cacaueiro. CEPLAC/CEPEC, Brasília/ Itabuna, 688p.

Monteiro WR and Ahnert D (2012) Melhoramento genético do cacaueiro. In Valle RR (ed) Ciência, tecnologia e manejo do cacaueiro. CEPLAC/ CEPEC, Brasília/Itabuna, 688p.

Oliveira ML and Luz EDMN (2005) Identificação e manejo das principais doenças do cacaueiro no Brasil. CEPLAC/CEPEC/SEFIT, Ilhéus, 132p.

Paim VRL, Luz EDMN, Pires JL, Silva SDVM, Souza JT, Albuquerque PSB and Santos Filho LP (2006) Sources of resistance to Crinipellis perniciosa in progenies of cacao accessions collected in the Brazilian Amazon. Scientia Agricola 63: 572-578.

Peres Filho AS (1998) A cadeia produtiva do cacau. In Agronegócio brasileiro: ciência, tecnologia e competitividade. $2^{\text {nd }}$ edn, CNPq, Brasília, p. 189-199.

Pires JL, Monteiro WR, Luz EDMN, Silva SDVM, Pinto LRM, Figueira A, Gramacho KP, Lopes UV, Albuquerque PSB, Yamada MM, Ahnert D and Brugnerotto MIB (1999) Cacao breeding for witches' broom resistance at CEPEC, Bahia, Brazil. In Proceedings of the international workshop on the contribution of disease resistance to cacao variety improvement. Ingenic, Malaysia, p. 910-1001.

Santos Filho LP, Pires JL, Ruiz MAM, Valle RR, Afonso JMC, Marrocos PCL and Freire ES (2008) Produção de cacau e a vassoura-de-bruxa na Bahia. Agrotrópica 20: 73-82.

SAS (1988) SAS/STAT User's Guide. Release 6.03. SAS Institute, Cary, $1028 \mathrm{p}$.

Silva SDVM, Luz EDMN, Pires JL, Yamada MM and Santos Filho LP (2010) Parent selection for cacao resistance to witches' broom. Pesquisa Agropecuária Brasileira 45: 680-685.

Silva SDVM and Matsuoka K (1999) Histologia da interação Crinipellis perniciosa e cacaueiros suscetível e resistente à vassoura-de-bruxa. Fitopatologia Brasileira 24: 49-53. 